\title{
PROWADZENIE DZIAŁALNOŚCI GOSPODARCZEJ I JEJ OGRANICZENIA W ZJEDNOCZONYCH EMIRATACH ARABSKICH
}

\begin{abstract}
WSTĘP
Prowadzenie działalności gospodarczej w krajach muzułmańskich budzi wciąż wiele kontrowersji w świecie zachodu, który zasad funkcjonowania tamtejszych gospodarek niekiedy nie rozumie, a niekiedy nie chce zrozumieć, chociaż niektóre z nich np. Emirat Dubaju uchodzą za wzór rozwoju, nie tylko w świecie islamu. Możliwość prowadzenia działalności gospodarczej przez podmioty prywatne została zagwarantowana w Konstytucji Zjednoczonych Emiratów Arabskich ${ }^{1}$. Podstawą gospodarki krajowej jest sprawiedliwość społeczna. Jest ona oparta na lojalnej współpracy między publiczną i prywatną działalnością. Jej celem jest osiągnięcie rozwoju gospodarczego, wzrostu wydajności, podniesienie standardów życia i osiągnięcie dobrobytu obywateli, wszystko w granicach prawa. Unia zachęca do współpracy i oszczędności (art. 24 Konstytucji ZEA). Działalność publiczna i prywatna są zatem równe wobec siebie w świetle prawa i powinny ze sobą lojalnie współpracować. Właśnie taka współpraca wyznacza standardy dla sprawiedliwości społecznej. Emiracka Konstytucja chroni także własność prywatną, a jej szczegółowy zakres jest określany przez ustawę. Nikt nie może być pozbawiony swojej prywatnej własności, z wyjątkiem przypadków podyktowanych pożytkiem publicznym, zgodnie z przepisami ustawy i na wypłatę sprawiedliwego odszkodowania (art. 21 Konstytucji ZEA). Konstytucyjna ochrona własności prywatnej jest

Mgr Mariusz Pajduszewski - doktorant w Katedrze Prawa Konstytucyjnego, Instytut Nauk Prawnych, Wydział Prawa, Prawa Kanonicznego i Administracji Katolickiego Uniwersytetu Lubelskiego Jana Pawła II, Al. Racławickie 14, 20-950 Lublin; e-mail: pajduszewski@icloud.com; https:// orcid.org/0000-0003-3716-4802

${ }^{1}$ Konstytucja Zjednoczonych Emiratów Arabskich z dnia 2 grudnia 1996 r. [dalej cyt.: Konstytucja ZEA], [w:] https://www.wipo.int/edocs/lexdocs/laws/en/ae/ae030en.pdf [dostęp: 17.01.2019].
\end{abstract}


jednocześnie swobodą działalności gospodarczej (art. 24). W sumie można więc uznać, że wskazane przepisy konstytucyjne wzajemnie się uzupełniają.

\section{MOŻLIWOŚCI PROWADZENIA DZIAŁALNOŚCI GOSPODARCZEJ W ZJEDNOCZONYCH EMIRATACH ARABSKICH}

Prawo w Zjednoczonych Emiratach Arabskich określa szczegółowe możliwości prowadzenia działalności gospodarczej: można założyć spółkę ze stałym przedstawicielstwem, ustanowić oddział spółki, utworzyć podmiot w ZEA strefie wolnocłowej, utworzyć spółkę cywilną (obecnie ograniczone do emiratu Sharjah i Dubaju) lub zawrzeć umowę pośrednictwa handlowego.

Prawo spółek handlowych w ZEA² wymaga, aby - co do zasady - każda firma z siedzibą w Zjednoczonych Emiratach Arabskich miała jednego lub więcej wspólników, którzy posiadają co najmniej 51\% kapitału spółki. Owi wspólnicy muszą być obywatelami ZEA (art. 10). Istnieją jednak wyjątki od tej zasady i firmy, które podejmują pewne czynności są zwolnione z, wymogu 51\%”: w tym firmy naftowe z umów koncesyjnych, firmy zaangażowane w przemyśle naftowym i gazowym, firmy, które produkują energię elektryczną i gaz, firmy zajmujące się uzdatnianiem wody oraz przemysłu i dystrybucji (art. 10) $)^{3}$. Banki zagraniczne są zwolnione z konieczności powoływania sponsora, czyli osoby odpowiedzialnej za pracownika, który pokrywa koszty związane z przystosowaniem pracownika do wykonywania pracy. Firmy z siedzibą w strefach wolnocłowych są zwolnione z ,wymogu 51\%”, jeżeli spełnią dodatkowe wymogi, jak uzyskanie licencji czy bardziej ograniczony wybór zakresu działalności regulujący funkcjonowanie spółki (art. 10) ${ }^{4}$.

Istnieje pięć różnych form prawnych, za pomocą których można prowadzić działalność gospodarczą w formie spółki ze stałym przedstawicielstwem. Są to: spółka współodpowiedzialna, spółka komandytowa, publiczne spółki akcyjne, prywatne spółki akcyjne, spółka z ograniczoną odpowiedzialnością.

Spółka współodpowiedzialna [Joint Liability Company] to spółka składająca się z dwóch lub więcej partnerów będącymi osobami fizycznymi, którzy odpowiadają solidarnie za zobowiązania spółki. Wspólny partner powinien mieć zdolność przedsiębiorcy. Uważa się, że partner osobiście prowadzi działalność handlową na rzecz spółki. Oświadczenie o upadłości spółki współodpowiedzialnej oznacza

\footnotetext{
${ }^{2}$ Ustawa Federalna nr 2 z dnia 1 kwietnia 2015 r. o spółkach handlowych [odpowiada 17 Dhi Al-Hijjah 1436 H. w kalendarzu muzułmańskim].

$3 \mathrm{https} / /$ www.government.ae/en/information-and-services/business/starting-a-business-in-a-free-zone [dostęp: 15.05.2014].

${ }^{4}$ http://www.lw.com/upload/pubcontent/_pdf/pub2783_1.pdf [dostęp: 15.05.2014].
} 
ogłoszenie bankructwa wszystkich partnerów mocą ustawy federalnej o spółkach handlowych (art. 39-61).

Spółka komandytowa [Simple Commandite Company] składa się z co najmniej jednego wspólnego partnera (komplementariusza), który odpowiada za zobowiązania spółki do pełnej wysokości swoich aktywów (bez ograniczeń), wraz z co najmniej jednym partnerem (komandytariuszem), odpowiadającym za zobowiązania spółki do wysokości wkładów kapitałowych, które wniósł na rzecz spółki. Podmiot ten ma zwykle jednego aktywnego wspólnika (komplementariusza), który ma wiedzę, pomysł i zarządza spółką oraz komandytariusza, który nie uczestniczy w zarządzaniu na co dzień, wykłada jednak kapitał niezbędny do prowadzenia działalności (art. 62-70).

Publiczna spółka akcyjna [Public Joint Stock Company] jest spółką, której kapitał dzieli się na równe i zbywalne udziały. Założyciele zobowiązani są do objęcia części takich akcji, podczas gdy inne akcje mają być oferowane publicznie w ramach publicznego obrotu. Akcjonariusz ponosi odpowiedzialność tylko w zakresie swojego udziału w kapitale spółki. Każda publiczna spółka akcyjna musi mieć nazwę handlową, która nie może być nazwą osoby fizycznej, chyba że celem spółki jest inwestowanie w patent wynalazcy zarejestrowany na nazwisko takiej osoby i/lub jeśli firma posiada nazwę handlową lub uzyskała prawo do używania takiej nazwy. We wszystkich przypadkach do nazwy firmy dodaje się wyrażenie „publiczna spółka akcyjna”. Do założenia publicznej spółki akcyjnej potrzebnych jest pięć lub więcej. Jedynie Rząd federalny, samorząd lokalny i każda spółka lub podmiot w pełni utrzymywany przez rząd federalny lub samorząd lokalny może być udziałowcem publicznej spółki akcyjnej lub posiadać samodzielnie publiczną spółkę akcyjną, a także może uczestniczyć we wkładzie do kapitału. Czas trwania spółki określa się w jej statucie i zgodnie z decyzją termin ten może zostać przedłużony lub skrócony, jeżeli wymaga tego cel przedsiębiorstwa (art. 105-142).

Prywatna spółka akcyjna [Private Joint Stock Company] to spółka, w której liczba akcjonariuszy wynosi co najmniej dwóch, ale nie więcej niż dwustu. Kapitał spółki dzieli się na akcje o tej samej wartości nominalnej, które muszą zostać w pełni opłacone bez wypuszczania jakichkolwiek akcji do publicznego obrotu. Poprzez podpisanie memorandum przestrzeganie przepisów umowy spółki akcjonariusz ponosi odpowiedzialność tylko w zakresie swojego udziału w kapitale spółki. Po nazwie spółki następuje wyrażenie „własność prywatna - prywatny akcyjny”. Wyemitowany kapitał spółki wynosi nie mniej niż 5000000 AED (ok. 1000 $000 €)$ i jest opłacony w całości. Limit ten może zostać zmieniony na wniosek na mocy decyzji Rady Ministrów. Prywatne spółki akcyjne istniejące i zarejestrowane w Ministerstwie przed datą wejścia w życie ustawy są wyłączone z minimalnego 
limitu kapitału określonego w ustawie, który wynosił wcześniej 2000000 AED $=$ ok. $400000 €($ art. 255-265).

Z kolei w skład spółki z ograniczoną odpowiedzialnością [Limited Liability Company] wchodzi minimum dwóch wspólników, jednak liczba wspólników nie może być większa niż 50. Odpowiedzialność każdego z nich jest ograniczona do wysokości ich udziałów w kapitale spółki. Po zmianie przepisów spółki z o.o. nie mają już różnych minimalnych wymogów kapitałowych: 300000 AED = ok. $60000 €$ (w Dubaju) oraz 150000 AED = ok. $30000 €($ w Abu Dhabi i pozostałych Emiratach). Zgodnie z obowiązującymi przepisami, „wystarczający kapitał" ma być indywidualnie określany przez Departament Rozwoju Gospodarczego właściwego Emiratu. Ma być brana pod uwagę wielkość i planowane działania spółki. Zagraniczne firmy, które chcą ustanowić spółkę z o.o. w Zjednoczonych Emiratach Arabskich powinny szukać wskazówek w zakresie bieżącej praktyki właściwego Emiratu dotyczących minimalnego kapitału zakładowego (art. 71-82).

Kolejną formą prowadzenia działalności są spółki zależne (spółki córki), w formie oddziału i biur łącznikowych. Oddział ma tę samą osobowość prawną jak spółka dominująca i prowadzi działalność pod nazwą spółki dominującej. Jednak każdy Emirat ma swoje własne zasady licencjonowania oddziałów. Tego typu jednostki mogą wykonywać różne czynności (zatwierdzone przez Departament Rozwoju Gospodarczego właściwego Emiratu). Oddziały są traktowane jako pełnoprawne firmy dopuszczone do wykonywania umów lub prowadzenia innych działań określonych w pozwoleniu. Na przykład, aby otworzyć filię w Abu Dhabi, spółka zagraniczna, musi przedstawić: a) dokument potwierdzający zarejestrowanie spółki w kraju pochodzenia ${ }^{5}$ (w Polsce takim dokumentem jest wydruk z KRS); b) potwierdzenie braku powiązań między dyrektorami, a zarządem spółki (lub innej właściwej jednostki administracyjnej) ${ }^{6}$; c) zgodność z oryginałem kopii aktu założycielskiego spółki zagranicznej lub jej statut; d) dwa ostatnie zatwierdzone sprawozdania finansowe spółki (bilans, rachunek zysków i strat oraz informacje dodatkowe do sprawozdania finansowego), oprócz raportu audytora; e) oświadczenie firmy skierowane do Ministerstwa Gospodarki ZEA, w którym zawarte jest zobowiązanie się do poniesienia wszelkich ciężarów finansowych wynikających z jego oddziałów w ZEA; f) pełnomocnictwo notarialne dla osoby, która podpisze

\footnotetext{
${ }^{5}$ Spółka ubiegająca się o rejestrację w Emiratach ma również obowiązek wskazania dokumentu, który potwierdza, że firma jest należycie zarejestrowane i ma siedzibę w tym kraju, wskazując formę prawną, opłacony kapitał, a także nazwę, tytuł i uprawnienia jej przedstawiciela.

${ }^{6}$ Dokument potwierdzający brak powiązań funkcyjnych lub rodzinnych. Powiązania są identyfikowane w sytuacji, gdy bezpośredni lub pośredni udział w kontroli lub zarządzaniu dwoma różnymi podmiotami mają osoby, między którymi istnieje pokrewieństwo lub powinowactwo.
} 
umowę agencyjną z firmą w Abu Dhabi, która będzie tę firmę wobec władz Abu Dhabi reprezentować.

Wszystkie powyższe dokumenty (z wyjątkiem wskazanego w pkt d) muszą być potwierdzone w Ambasadzie ZEA w kraju pochodzenia. Ponadto, wszystkie powinny być przetłumaczone na język arabski w ZEA i poświadczone przez tłumacza przysięgłego ZEA i potwierdzone przez Ministerstwo Sprawiedliwości ZEA ${ }^{7}$.

Ponadto należy uzyskać następujące dodatkowe dokumenty, które mają być przedstawione przez przedstawiciela firmy ubiegającej się o prawo jazdy w oddziale. Jednak te dokumenty nie muszą być potwierdzone przez jednostki administracyjne ZEA. Są to: a) wniosek koncesyjny; b) szczegółowy zakres działalności firmy; c) umowa agencyjna zawarta pomiędzy firmą zagraniczną i lokalnym agentem; d) lista najważniejszych przedsięwzięć prowadzonych przez spółkę poza ZEA wraz $\mathrm{z}$ dotychczasowym doświadczeniem w zakresie działalności, najlepiej z uwzględnieniem krajów muzułmańskich, w których takie działania miały miejsce; e) zestawienie pokazujące liczbę pracowników przewidzianych do powołania w oddziale firmy w Abu Dhabi; f) kapitał obrotowy oddziału nie może być niższy niż 250000 AED co stanowi równowartość ok. $50000 €$, co do których może istnieć wymóg zdeponowania w banku w Abu Dhabi. Alternatywnie, Ministerstwo Gospodarki ZEA może zażądać bezwarunkowej gwarancji płatności banku, który ma swoją siedzibę w ZEA na rzecz Ministerstwa do wysokości 50000 AED (ok. $10000 €)^{8}$.

Oddział lub biuro łącznikowe jest ograniczone do promowania działalności swojej spółki dominującej. Oznacza to, że przedstawicielstwo jest dozwolone tylko do wykonywania tych czynności, jak zbieranie informacji, zabieganie o zlecenia czy projekty marketingowe, które mają być wykonywane przez spółkę dominującą. Ten rodzaj spółki córki jest zazwyczaj ograniczony co do liczby pracowników, których spółka jest sponsorem (na ogół trzech do czterech) ${ }^{9}$.

Istotną rolę w gospodarce ZEA odgrywają strefy wolnocłowe. Prawo umożliwia również zagranicznym firmom prowadzenie działalności w specjalnych strefach wolnocłowych. Wolne obszary pozwalają na 100\% własność zagranicznego inwestora i podlegają mniejszym i korzystniejszym dla nich barierom handlowym i taryfom. Jednak firmy w wolnym obszarze celnym mogą działać jedynie w granicach wolnej strefy i są zazwyczaj ograniczone do wykonywania wyłącznie czynności wymienionych $\mathrm{w}$ ich licencji. Jeśli firma zdecyduje się działać poza tymi granicami, musi stosować się do wymogów ustawy ZEA spółek handlowych, zgodnie

\footnotetext{
${ }^{7} \mathrm{http}: / /$ www.uaetrade-usa.org/index.php?page=uae-economy\&cmsid=105 [dostęp: 15.05 .2014$]$.

${ }^{8}$ http://www.lw.com/upload/pubcontent/_pdf/pub2783_1.pdf [dostęp 15.05.2014].

${ }^{9} \mathrm{https} / / / \mathrm{www}$. adjd.gov.ae/EN/pages/legal\%20guidance/sb-licensegulfcompanyforeign.aspx [dostęp: 23.01.2019.
} 
z procedurą licencjonowania na zastosowanie Emiratu. Generalnie, strefy wolnocłowe są wyznaczane przez rząd dla konkretnego sektora komercyjnego. Istnieją zatem różne rodzaje licencji, które mogą być emitowane w strefie wolnocłowej, są to: a) licencja General Trading; b) licencja handlowa; c) licencja przemysłowa; d) licencja usługowa; e) licencja przemysłowa, krajowa ${ }^{10}$.

Każdy Emirat posiada swoje strefy wolnocłowe, które mają przyspieszyć wzrost gospodarczy kraju. Warto wymienić największe chociażby w Emiracie Abu Dhabi, który posiada takie strefy, jak: Twofour54 wolna strefa dla mediów, Wolna strefa miasta Masdar [Masdar City Free Zone], Lotnisko Abu Dhabi Wolna Strefa, Strefa przemysłowa Khalifa port. Zdecydowanie najwięcej stref wolnocłowych posiada Emirat Dubaju, bo aż $17^{11}$. W dalszej kolejności są Emiraty Sharjah: Sharjah Airport Free Zone [SAIF Zone] i Hamriyah Free Zone [HFZ]; Emirat Ra's Al Chajma: Ra's AL Chajma Free Trade Zone [RAKFTZ], Ra's Al Chajma Free Media Zone i Ra's Al Chajma Investment Authority [Rakia]; Emirat Fujairah: Fujairah Free Zone [FFZ] i Fujairah Creative City; Emirat Ajman: Ajman Free Zone [AFZ], Emirat Umm Al Quwain: Ahmed Bin Rashid Free Zone ${ }^{12}$.

Należy wspomnieć także o możliwości prowadzenia spółki cywilnej. Jest ona dostępna jedynie w Emiratach Dubaju i Sharjah. Podmioty te działają na podstawie licencji. Spółki cywilne nie są zazwyczaj przeznaczone do handlu (np. zaangażowanie się w zakup i sprzedaż towarów, wykonawstwo, transport, bankowość i finanse), ale są wykorzystywane przez poszczególne branże. Konstrukcją przypominają bardziej spółkę partnerską z polskiego kodeksu spółek handlowych.

Zagraniczne firmy mogą także zawrzeć umowę pośrednictwa handlowego i angażować się w organizację i rozwój biur handlowych, w których zagraniczna firma jest reprezentowana przez przedstawiciela w ZEA, który może rozpowszechniać, sprzedawać lub dostarczać towary i wykonywać usługi na terytorium Emiratu w zamian za prowizje od zysku. Taką umowę można podpisać zarówno z osobą posiadającą obywatelstwo ZEA lub firmą, która jest w 100\% własnością obywateli ZEA. Umowa pośrednictwa handlowego jest rejestrowana w Ministerstwie Gospodarki, chyba, że owa umowa stanowi inaczej. W każdym wypadku umowa musi być sporządzona na piśmie i podpisana przez strony. Jeżeli nie uzgodniono

\footnotetext{
${ }^{10} \mathrm{http}: / /$ www.uaetrade-usa.org/index.php?page=uae-economy\&cmsid=105 [dostęp: 15.05.2014].

${ }^{11}$ Jebel Ali Free Zone [JAFZ], Dubai Airport Free Zone [DAFZ], Dubai Internet City [DIC], Dubai Media City [DMC], Dubai Gold and Diamond Park [DGDP], Dubaj Cars \& Automotive Zone, Dubai Health Care City [DHCC], Dubai International Financial Centre [DIFC], Dubai Maritime City, Dubai Logistics City, Dubai Knowledge Village, Dubai Outsource Zone [DOZ], Dubai Techno Park [DTP], Dubai Silicon Oasis Authority [DSOA], Dubai Studio City [DSC], Dubai Textile City [DTC], Dubai Flower Centre [DFC], Dubai Carpet Free Zone, Jumeirah Lakes Towers Free Zone [JLT].

${ }^{12} \mathrm{http} / / /$ www.uaetrade-usa.org/index.php?page=uae-economy\&cmsid=105 [dostęp: 15.05.2014].
} 
inaczej - agent jest uprawniony do otrzymania prowizji od sprzedaży produktów w swoim wyznaczonym Emiracie, niezależnie od tego, czy sprzedaż ta była dokonywana przez lub za pośrednictwem agenta.

Wszystkie firmy wymagają licencji, a procedury licencyjne są różne w poszczególnych Emiratach Jest to zgodne z rzeczywistością określoną przez Izby Handlu i Przemystu ${ }^{13}$.

Istnieje jeszcze kilka pozostałych możliwości prowadzenia działalności gospodarczej, jak chociażby spółki offshore: wprowadzone w 2003 r. rozporządzeniem w Jebel Ali Free Zone [JAFZ] ${ }^{14}$. Na podstawie tego aktu umożliwiono zagranicznym podmiotom tworzenie spółki typu offshore w JAFZ, podobne do innych międzynarodowych jurysdykcji offshore. Emirat Ra's Al Chajma zezwolił na utworzenie spółki offshore w 2006 r. Jednak w ostatnich latach tego typu spółki kojarzone są jedynie z agresywną optymalizacją podatkową, a ich działalność została znacznie ograniczona przez kraje OECD i międzynarodowy system bankowy ${ }^{15}$.

Warto wspomnieć również o zamówieniach sektora publicznego: Każdy emirat ma szczegółowe przepisy regulujące działalność zamówień rządowych. Praca w sektorze publicznym jest zwykle przyznawana na podstawie ustawy o zamówieniach publicznych, która określa minimalne normy w odniesieniu do zamówień publicznych na terytorium ZEA. Na przykład zamówienia obronne mają właściwe dla swojej branży regulacje.

Należy też pamiętać o wyspecjalizowanych strefach ekonomicznych. W ZEA znajduje się szereg stref ekonomicznych, jak te ustanowione przez ZonesCorp w Abu Dhabi, które oferują zachęty inwestycyjne, jak refundacje w kosztach dostosowania infrastruktury do prowadzonej działalności, wsparcie administracyjne, uproszczenie procesów i atesty miast dla pracowników. Firmy znajdujące się w wyspecjalizowanych strefach ekonomicznych podlegają jednak ,wymogowi 51\%”.

Jest również możliwość przyspieszenia procesu uzyskania licencji do prowadzenia działalności poprzez uzyskanie tzw. Dubaj Licencja Fast-Track. Departament Rozwoju Gospodarczego w Dubaju [DED] oferuje przyspieszoną licencję handlową, która będzie ważna przez 120 dni, co daje firmom czas, aby nie tylko wypełnić

\footnotetext{
${ }^{13}$ W każdym przypadku należy skontaktować się z jedną z Izb Handlu i Przemysłu, właściwą dla konkretnego Emiratu, są to: Abu Dhabi Chamber of Commerce \& Industry, Ajman Chamber of Commerce \& Industry, Dubai Chamber of Commerce \& Industry, Fujairah Chamber of Commerce \& Industry, Ra's Al Chajma Chamber of Commerce \& Industry, Sharjah Chamber of Commerce \& Industry, Umm Al Quwain Chamber of Commerce \& Industry, zob. http://www.lw.com/upload/ pubcontent/_pdf/pub2783_1.pdf [dostęp: 15.05.2014].

${ }^{14} \mathrm{http} / / /$ jafza.ae/rules-regulations/Rules-and-regulation.pdf [dostęp: 17.01.2019].

${ }^{15} \mathrm{http}: / /$ www.oecd.org/tax/the-oecd-takes-further-steps-to-putting-an-end-to-offshore-tax-evasion. htm [dostęp: 17.01.2019].
} 
oficjalne dokumenty, zezwolenia i rejestracje, ale także umożliwia zatrudnienie pracowników, testowanie produktów i ustanowienie nowych przedsięwzięć. Umowa najmu i historia pracy właściciela firmy stanowią jedyne bariery do uzyskania wstępnego pozwolenia ${ }^{16}$.

Ponadto warto zaznaczyć, iż największą zachętą do prowadzenia działalności gospodarczej jest brak podatku dochodowego, z wyjątkiem spółek naftowych i banków, a także nie ma podatku od sprzedaży ${ }^{17}$. Podatek od wartości dodanej, czyli VAT wynosi 5\% i został wprowadzony dopiero 1 stycznia 2018 r. ${ }^{18}$

\section{OGRANICZENIA WOLNOŚCI DZIAŁALNOŚCI GOSPODARCZEJ W ZJEDNOCZONYCH EMIRATACH ARABSKICH}

Ważnym elementem prowadzenia działalności gospodarczej w Zjednoczonych Emiratach Arabskich poza maksymalizacją zysku, jest realizacja pozaekonomicznych celów gospodarki, tj. religijnych i społecznych, związanych z cywilizacją i kulturą islamu.

Do zasadniczych cech wyróżniających prowadzenie działalności gospodarczej, ale i system finansowy w ZEA należą: a) podział ryzyka między kontrahentów, b) oparcie działań gospodarczych o normy etyczno-moralne, c) zwrócenie uwagi na rezultat i użyteczność przedsięwzięcia, a nie sytuację finansową i zdolność kredytową, d) zmniejszanie różnic dochodowych w społeczeństwie ${ }^{19}$.

Te dość specyficzne zasady są w istocie ograniczeniem wolności gospodarczej, chociaż są społecznie pożyteczne i akceptowane. W istocie podział ryzyka między kontrahentami, wydaje się oczywisty, jednak polskie prawo handlowe dopuszcza wyłączenie z udziału w stratach spółki. Zatem ryzyko nie rozkłada się równomiernie. Takie rozwiązania są niezgodne $\mathrm{z}$ islamem, gdyż podstawą funkcjonowania $\mathrm{w}$ gospodarkach krajów islamskich jest teoria pieniądza. Dlatego istnieje konieczność, by odpowiedzieć na pytanie: czym jest pieniądz w finansach islamskich. Przede wszystkim jest środkiem wymiany, miernikiem wartości, wyznacza wartość odroczonych płatności. Sam w sobie pieniądz nie posiada wartości, jest wyłącznie potencjalnym kapitałem, co sprowadza się do wniosku, że nie można przez jego posiadanie zdobywać zysku. Nie jest on towarem, który można kupić po pewnej cenie i sprzedać po wyższej. Dlatego nie należy się skłaniać do gromadzenia pie-

\footnotetext{
${ }^{16} \mathrm{http}: / /$ www.uaetrade-usa.org/index.php?page=uae-economy\&cmsid=105 [dostęp: 15.05.2014].

${ }^{17} \mathrm{http}: / /$ www.lw.com/upload/pubcontent/_pdf/pub2783_1.pdf [dostęp: 15.05.2014].

${ }^{18} \mathrm{https}$ ://government.ae/en/information-and-services/finance-and-investment/taxation/valueaddedtaxvat [dostęp: 17.01.2019].

${ }^{19}$ J. ADAMEK, Mikrofinanse islamskie, Warszawa: CeDeWu 2010.
} 
niądza, ale do wykorzystywania jego potencjału, poprzez dokonywanie zakupów, szczególnie inwestycyjnych, by pieniądz nie był bezproduktywny. Dopiero, gdy pieniądz bierze udział w procesach gospodarczych uzyskuje swoją wartość. Zatem praca, inicjatywa i ryzyko mogą przynosić efekty gospodarcze i właśnie one są nagradzane zyskami. Według islamskich badaczy, zwiększanie produktywności gospodarki, ujawniające się w powiększaniu aktywów, produktów i usług stanowi o sile gospodarczej. Pieniądz ma za zadanie jedynie pośredniczyć w wymianie dóbr i usług, ułatwiać w wycenie i dokonywaniu transakcji ${ }^{20}$.

Biorąc pod uwagę, iż do osiągnięcia zysku konieczne jest podjęcie ryzyka, strony przyczyniające się do powstania przedsięwzięcia gospodarczego, czyli przedsiębiorca, wnoszący swój czas, wiedzę i pracę oraz inwestor, wnoszący kapitał, są zobowiązani do partycypacji zarówno w zyskach, jak i stratach, wynikających $\mathrm{z}$ owego przedsięwzięcia. Islam, nakłaniając do wchodzenia wyżej wymienionych stron we współpracę, zrównuje je ze sobą, a także stawia na takim samym poziomie wartość czynników produkcyjnych, które są wkładem obu stron. Jest to inwestowanie o podwyższonym ryzyku wobec rozwiązań znanych z finansów europejskich, takich jak rachunki oszczędnościowe, lokaty czy obligacje. Jednak zachowana jest proporcja między wysokością ryzyka, a możliwością wyższego zwrotu z inwestycji. Ze skłonności do podziału zysków i strat w inwestowaniu wynika istnienie teorii podziału zysku i straty, czyli PLS [Profit and Loss Sharing Theory], a także model o tym samym symbolu - PLS. W rezultacie obie strony są bardziej zaangażowane w proces działalności i nakłonione do efektywnej realizacji, gdyż obu stronom w takim samym stopniu zależy na rezultatach, wynikających z działań inwestycyjnych, bo z nich wynika zysk. Ta zasada odnosi się nie tylko do przedsiębiorców działających wspólnie, ale do całego systemu finansowego. Zatem banki islamskie również zupełnie inaczej podchodzą do pojęcia ryzyka kredytowego. Bank nie tylko kontroluje przedsiębiorstwo i jego działania, ale także z nim współpracuje i je wspiera. Jest to bliższa relacja banku z przedsiębiorstwem niż polegająca jedynie na ocenie zdolności kredytowej. Wobec europejskiego modelu, w którym bank jest kredytodawcą, bank islamski wchodzi w rolę inwestora. Kapitał finansowy inwestowany jest niejako bezpośrednio w aktywa - w takiej sytuacji ewentualny zysk będzie wypracowany przez aktywa, a nie przez pieniądze ${ }^{21}$.

Oparcie działań gospodarczych o normy etyczno-moralne również stanowi pewną formę ograniczenia możliwości prowadzenia działalności. Istota bankowości europejskiej, ale i rynków finansowych, jak i obiegu pieniądza w gospodarce

\footnotetext{
${ }^{20} \mathrm{http}: / /$ www.arabia.pl/content/view/279728/2/ [dostęp: 20.04.2014].

${ }^{21}$ M.A. BoncA, Islamskie instrumenty finansowe, Warszawa: Wydawnictwa Akademickie i Profesjonalne 2010 .
} 
polega na zaufaniu. Jednak jest to zaufanie do instytucji, głównie banków, ale w przypadku, gdy bank stanie się niewypłacalny, depozyty gwarantuje państwo (kwota depozytów nieprzekraczająca równowartości w złotych 100000 euro jest gwarantowana $\mathrm{w}$ całości ${ }^{22}$ ). Jest to zatem zaufanie do instytucji (bank czy państwo) natomiast w ZEA ufa się ludziom, a nie instytucjom. Potencjalny partner biznesowy musi nie tylko budzić zaufanie, ale i również zdobyć owe zaufanie wśród ludzi biznesu w ZEA, jak chociażby zaufanie do Emira, Szejka, który zobowiązał się do wybudowania szpitala czy szkoły. W świecie „biznesów arabskich” bardzo ważną rolę odgrywa rodzina. Wiele rozmów biznesowych rozpoczyna się najpierw od pytań o rodzinę. Arabowie, a zwłaszcza Emiratczycy są szczególnie wyczuleni na tym punkcie. Przez posiadanie rodziny sprawdza się kręgosłup moralny; jeśli mój potencjalny partner jest dobrym mężem i ojcem, potrafi utrzymać rodzinę, to poradzi sobie w biznesie. Jednak pytania o sprawy osobiste nie mają jedynie charakteru sprawdzania drugiej strony, generalnie Emiratczykom zależy na tym by po prostu poznać drugą stronę, porozmawiać nie o biznesie, a o sprawach życia codziennego, o troskach i radościach płynących z życia, o pasjach drugiej strony. Dopiero, gdy uda się zdobyć szacunek i zaufanie partnera, wzajemne odwiedziny stają się okazję do wynikających z tej znajomości rozmów o biznesie. W świecie zachodnim biznes ma rację, gdy jest opłacalny, tzn. opłaca się obu stronom. Natomiast w świecie arabskim, nie zysk jest najważniejszy, a zaufanie: jeśli ufam swojemu partnerowi to godzę się na zysk, ale i stratę bez zbędnych, z arabskiego punktu widzenia umów. Wzajemne poznanie się rodzin jest również bardzo ważne, gdyż nie tylko potencjalni partnerzy biznesowi nabierają do siebie zaufania, ale również całe rodziny. To wzmacnia więzi. Relacje nie są czysto biznesowe, ale rodzinne. Podchodzimy zatem do swojego partnera jak do swojej własnej rodziny. Tylko będąc na takim poziomie można pozwolić sobie na robienie późniejszych interesów, które powinny wynikać z potrzeby chwili, ze sprzyjających warunków, wspólnych przemyśleń, nie powinny być dużo wcześniej przygotowane, znajomość nie powinna być z góry nastawiona na biznes, tylko na zdobycie szacunku i przyjaźni, a biznes jest niejako na drugim miejscu.

Szczególną uwagę zwraca się na rezultat i użyteczność przedsięwzięcia, a nie sytuację finansową i zdolność kredytową. Środki finansowe na przedsięwzięcie uda się zgromadzić, jeśli owe przedsięwzięcie będzie wysoce użyteczne, a jego rezultat niejako społecznie, jak również biznesowo pożądany. Jeśli partnerom nie uda się zgromadzić odpowiednich środków finansowych to z pomocą przyjdzie bank, który udzieli kredytu, ale na zasadach islamskich; bez odsetek i prowizji, natomiast bank będzie partycypował w zyskach. Zatem w pewnym sensie znale-

\footnotetext{
${ }^{22}$ https://www.bfg.pl/kwota-objeta-gwarancja [dostęp: 17.05.2014].
} 
zienie przedsięwzięcia społecznie pożytecznego, aby uzyskać źródła finansowania, wydaje się być ograniczeniem z punktu widzenia prowadzenia działalności gospodarczej. Jednak z drugiej strony fakt, iż inicjatywa powstania przedsięwzięcia, a nie sytuacja finansowa decyduje o przyznaniu środków, jak również brak odsetek w zamian za udział w zyskach jest znacznym ułatwieniem.

Każdy potencjalny przedsiębiorca planujący rozpoczęcie działalności gospodarczą na terytorium ZEA powinienem zapoznać się z kanonem zasad etycznych panujących w tym kraju, które wynikają $\mathrm{w}$ równej mierze $\mathrm{z}$ przepisów prawa, religii i kultury. M. Obaidullah do głównych etycznych norm finansów islamskich zalicza: a) wolność do zawierania umów; b) wolność od Al Riba; c) wolność od Al Gharar; d) wolność od Al-Qimar i od Al-Maysir; e) wolność od kontroli i manipulacji cenowej; f) prawo do transakcji zawierającej cenę sprawiedliwą; g) prawo do symetrycznej, odpowiedniej i szczegółowej informacji; h) wolność od Darar; i) wzajemną współpracę i solidarność.

Warto zatem wyjaśnić wymienione wyżej pojęcia. Wolność do zawierania umów jest podstawową wolnością islamu. Jej nieważność może być stwierdzona, gdy istniał jakikolwiek przymus zawarcia umowy, odnoszący się przynajmniej do jednej strony. Wolność ta jednak nie jest bezgraniczna. Inne nakazy lub zakazy prawa nie pozwalają np. na produkcję niektórych towarów lub podejmowanie się niektórych działalności. Dlatego zawieranie umów nie jest dozwolone w każdym przypadku. Obszarami gospodarczymi, którymi muzułmanie nie powinni się zajmować, są: a) produkcja lub dystrybucja broni, alkoholu, wyrobów tytoniowych, wieprzowiny i pornografii; b) kontrola urodzeń (odnosi się to do producentów środków antykoncepcyjnych albo np. klinik zapłodnień in vitro); c) hazard, gry losowe; d) restauracje, hotele, kina i inne lokale oferujące alkohol; e) inwestycje $\mathrm{w}$ instrumenty finansowe, które mają z góry założony zysk lub w instytucje finansowe oferujące takie instrumenty; f) nie są zalecane inwestycje w instrumenty pochodne (derywaty), m.in. w opcje, swapy, akcje uprzywilejowane ${ }^{23}$.

Zatem, co do zasady wolność, od zawierania umów przypomina swobodę zawierania umów z polskiego kodeksu cywilnego. Polski ustawodawca wprowadza ograniczenia, co do treści lub celu umowy, które nie mogą sprzeciwiać się naturze stosunku, ani ustawom, ani zasadom współżycia społecznego ${ }^{24}$.

Al Riba nie ma jednoznacznej definicji, dlatego istnieją spory na tle prawa, odnośnie do jej zakazów. Znaczenie riba powiązane jest ze wzrostem. Jedna z definicji riba thumaczona jest jako dowolny przyrost sumy, która ma być zwrócona

${ }^{23}$ M. Obaidullah, Islamic Financial Services, Jeddah: Islamic Economics Research Center 2005, s. 121.

${ }^{24}$ Art. $353 \S 1$ ustawy z dnia 23 kwietnia 1964 r. Kodeks cywilny, Dz. U. Nr 16, poz. 93. 
pożyczkodawcy, naliczony nad podstawę pożyczonego kapitału, czyli nad kwotę udzieloną pożyczkobiorcy w chwili zawarcia umowy. Druga definicja opisuje riba jako wykorzystywanie potrzebującego finansowego wsparcia pożyczkobiorcy, który znajduje się w niekorzystnej sytuacji gospodarczej. Powiększanie swojego majątku kosztem gorzej sytuowanych, przez wymaganie od nich odsetek nie znajduje przyzwolenia w ZEA. Koran zachęca wręcz do udzielania dobroczynnych pożyczek (qardhasan), czyli takich które nie zawierają żadnych dodatkowych opłat, a jeśli to możliwe, zrzeczenie się całego długu (potraktowanie długu jako jałmużny). Właśnie w taki sposób należy postępować, by zmniejszać różnice dochodowe w społeczeństwie. Jeszcze w czasach przedislamskich istniał termin zjawiska zabronionego przez Koran, czyli riba podwójnie podwojonego. Zjawisko to polegało na tym, że dłużnik, który po okresie spłaty nie mógł spłacić swojego długu, prosił o przedłużenie terminu w zamian za podwojenie długu. Po drugim okresie dług był dwukrotnie wyższy od pierwotnego, po trzecim czterokrotnie dłuższy, po piątym ośmiokrotnie, itd. Dług przyrastał zgodnie z funkcją wykładniczą o podstawie 2. Mimo, że przed udzieleniem pożyczki nie ustalano żadnych opłat, to w sytuacji braku możliwości spłaty opłata się podwajała. Przez co nawet niewielkie sumy, tworzyły znacznie większe długi. A riba oznaczała powiększenie pierwotnego zadłużenia w zamian za przedłużenie terminu spłaty długu ${ }^{25}$. System bankowości europejskiej premiuje tych, którzy mają zdeponowane pieniądze w bankach, oferując im wynagrodzenie w postaci odsetek. $Z$ drugiej strony wymaga wnoszenia odsetek i opłat od tych, którzy potrzebują pieniędzy. Zatem to pożyczkobiorca powiększa w sposób pośredni bogactwo, tych którzy kapitał posiadają, niezależnie od tego, jaki efekt przyniesie wypożyczony i zainwestowany kapitał pieniężny. Za wyjaśnienie stosowania zakazu riba warto zacytować słowa muzułmańskiego filozofa sprzed dziewięciu wieków: ,[...] Riba (odsetki) są zakazane, ponieważ powstrzymują ludzi od rzeczywistej aktywności gospodarczej. Tak się dzieje, gdy osobie posiadającej pieniądze wolno zarabiać na odsetkach w sposób łatwy i pozbawiony zmartwień, jakie towarzyszą trudowi realnej aktywności gospodarczej. Prowadzi to do ograniczeń w realizacji interesu społecznego, gdyż interes ten nie może być chroniony bez rzeczywistych umiejętności handlowych czy produkcyjnych [...]"26. Zatem riba nie jest pojmowane jako ograniczenie wolności działalności gospodarczej, a ów zakaz ma zachęcić do większej aktywności gospodarczej, poprzez eliminacje łatwego zysku bez odpowiedniego ryzyka.

${ }^{25}$ BoncA, Islamskie instrumenty, s. 65.

${ }^{26}$ AdameK, Mikrofinanse islamskie, s. 61; por. Al-Ghazali, Ihya-ul-Uloom, cyt. za: SHaikH A. Hamid, Philosophy and Practice of Islamic Economics and Finance, Working Paper No. 200601, [w:] https://academicarchive.snhu.edu/bitstream/handle/10474/1663/cfs2006-01.pdf?sequence=1 [dostęp: 17.01.2019]. 
Al Gharar można najogólniej tłumaczyć jako oszustwo, jednak pełna definicja jest znacznie szersza, gdyż hasło al gharar zawiera w sobie więcej niż tylko zakaz oszukiwania. Pojęcie oznacza również odrzucenie marnotrawstwa i próżności. Jak pisze Ibn al-Arabi, przez marnotrawstwo uważa się także: „nawiązywanie współpracy z innymi członkami społeczności w sposób niezgodny z szariatem, a w rezultacie osiąganie korzyści materialnych kosztem swoich kontrahentów w sposób nieuprawniony"27. Podobnie jak to było w przypadku riba, nie można wykorzystywać swojej silnej pozycji do tworzenia niekorzystnych relacji dla partnera transakcji. Zachodni kapitalizm sprowadza się najogólniej do zasady, iż „większy” gracz na rynku może więcej, decyduje wielkość kapitału. Ta prosta zasada znajduje odzwierciedlenie w powiedzeniu: too big to fail, czyli zbyt duży by upaść, a owe powiedzenie odnosi się do wielkich organizmów gospodarczych, jakimi są banki. W definicji al gharar zawiera się również wspomniany w kwestii zaufania nakaz budowania relacji przy równym dostępie do informacji, gdyż asymetria informacji, byłaby wykorzystaniem silniejszej pozycji na niekorzyść partnera. Gharar definiowane jest również jako relacja między stronami w transakcji, w której towar bądź usługa, będące przedmiotem transakcji, nie są lub nie mogą być pod kontrolą żadnej ze stron w chwili zawarcia umowy. Odnosi się to do umów, w których przedmiot umowy nie jest w posiadaniu ani jednej ze stron. Dotyczy to również sytuacji, gdy istnienie tego przedmiotu jest niepewne, a także gdy uzyskanie tego przedmiotu jest wątpliwe. Gharar odnosi się również do istotnych cech towaru, takich jak ilość, jakość czy możliwość odtworzenia, gdyby nastąpiło nieszczęśliwe zdarzenie, prowadzące do zniszczenia w trakcie obowiązywania umowy, a przed jej zakończeniem. Ma to zapewnić dokładniejsze zapoznanie się ze stronami umowy, jak i z umową, by w lepszy sposób spełnić oczekiwania tejże umowy. Gharar znajduje zastosowanie w transakcjach na rynkach finansowych, gdyż derywaty wiążą się z nieznajomością ich wartości, spekulacją i nie odzwierciedlają rzeczywistych aktywów. Niedopuszczalne jest także przenoszenie (scedowanie) ryzyka, bądź jego zbywanie, tym bardziej, że niełatwo określić jego wartość. Niemożliwe jest, by w pełni zadbać, by każdy miał dostęp do równej informacji, czy przewidzieć potencjalne ryzyko, aczkolwiek zakaz gharar prowadzić ma do precyzyjnego i jasnego konstruowania umów. Nie jest to ścisły i jednoznaczny zakaz, zależy on głównie od interpretacji ${ }^{28}$.

Al Qimar i Al Maysir oznacza hazard i niezasłużone dochody. Zakaz ten dotyczy nie tylko pozyskiwania dochodów z gier losowych, ale także zawieranie transakcji w niepewnej sytuacji bądź poprzez spekulacje. Kontrakt nie może przybrać for-

\footnotetext{
${ }^{27}$ BoncA, Islamskie instrumenty, s. 77.

${ }^{28}$ BoncA, Islamskie instrumenty, s. 78.
} 
my zakładu. Dopiero dokładna analiza i zgłębienie informacji mogą pozwolić na zawarcie zgodnej z islamem umowy ${ }^{29}$.

Kontrola i manipulacja cenowa są przez islam zakazane. Ceny kształtować się powinny przez siły popytu i podaży, bez żadnych ingerencji. Wpływanie na popyt lub podaż w celu zmiany ceny jest również niedopuszczalne. Niektórzy uczeni islamu dają możliwość działania, które miałoby zwalczać anomalie rynku, sprzeczne z konkurencją rynkową.

W ZEA subsydiowane przez rząd są podstawowe dobra, jak paliwo czy chleb, co ma również służyć wyrównywaniu różnic w społeczeństwie.

Prawo do transakcji zawierającej cenę sprawiedliwą, zakłada, że ceny powstają z gry rynkowej. Oznacza to, iż nie jest akceptowane, by korzystać z wyceny wynikłej z własnych szacunków, należy więc transakcje prowadzić zgodnie z cenami obowiązującymi na rynku, czyli ceną godziwą, inne nie są zgodne z religią.

Prawo do symetrycznej, odpowiedniej i szczegółowej informacji jest niezmiernie ważnym zagadnieniem, gdyż odgrywa istotną rolę w umowach handlowych, jak również przy podejmowaniu inwestycji. Zabrania się podawania nieprawdziwych informacji lub zatajenia istotnych dla umowy kwestii; również niepożądana jest niedokładność. Transakcji można dokonywać dopiero po zapoznaniu się ze wszystkimi istotnymi informacjami, w innym wypadku umowa jest nieważna w rozumieniu islamu. Ma to istotne znaczenie w inwestowaniu w papiery wartościowe, gdzie potrzebny jest stały i równy dostęp inwestorów do informacji dotyczących wyceny majątku, zmian warunków inwestycyjnych czy oczekiwań strumieni finansowych.

Darar to uszczerbek dla pewnej strony, która nie bierze udziału w transakcji, wynikły z zawarcia umowy przez dwie inne strony. Dla strony, która ponosi niekorzyść wynikają pewne prawa w związku z jej niezawinionymi stratami. Przykładem może być również niekorzystna sytuacja mniejszościowego akcjonariusza, który - w wyniku decyzji akcjonariuszy większościowych - może ponieść szkodę.

Wzajemna współpraca i solidarność jest nakazem, który wydaje się mało istotny, a wynika $\mathrm{z}$ tradycji islamskiej. Warto podkreślić, iż stosowany jest $\mathrm{w}$ finansach islamskich. Jest to pierwotny nakaz islamu. Sytuacja życia przedislamskiego, często koczowniczego trybu życia, w którym nie można było żyć w samotności, a przetrwać można było jedynie w grupie, wymusiła współpracę ${ }^{30}$.

Zatem, mamy do czynienia z wieloma nakazami i zakazami, które pośrednio lub bezpośrednio dotyczą prowadzenia działalności gospodarczej w ZEA. Za podsumowanie powinien posłużyć w pewnej mierze powtórzony z jednego z fragmentów spis obszarów życia gospodarczego, w które nie można inwestować zgodnie z islamem,

\footnotetext{
${ }^{29}$ Obaidullah, Islamic Financial, s. 93.

${ }^{30}$ Tamże, s. 95.
} 
są to: a) produkcja i dystrybucja alkoholu i tytoniu; b) produkcja wieprzowiny; c) pornografia; d) lokale sprzedające alkohol (w tym kina, restauracje, bary); e) kontrola urodzeń (np. producenci środków antykoncepcyjnych, kliniki zapłodnienia in vitro); f) miejsca $z$ ofertą gier hazardowych; g) finansowanie instytucji mających $\mathrm{w}$ ofercie konwencjonalne produkty finansowe, których zysk jest $\mathrm{z}$ góry ustalony, czyli oparte na odsetkach (chodzi tu m.in. o banki, fundusze inwestycyjne); h) przedsiębiorstwa, których wskaźnik zadłużenia oprocentowanego wynosi ponad $30 \%$ lub gdy należności stanowią połowę ich aktywów albo gdy przedsiębiorstwo nie posiada aktywów trwałych; i) dyskusyjne są inwestycje w instrumenty pochodne (futures, opcje, swapy i inne) $)^{31}$.

\section{ZAKOŃCZENIE}

Reasumując, na pojęcie wolności działalności gospodarczej należy patrzeć wielowymiarowo, nie tylko w kontekście danego kraju, lecz często w kontekście całego regionu, a nawet świata. Inwestorzy po kryzysie stali się bardziej wymagający i szukają najlepszych miejsc do prowadzenia interesów. Ważnym elementem jest prezentowanie polityki otwartości na inwestorów zagranicznych przez sprawne i szybkie dostosowywanie przepisów do wymogów rynku. Elastyczny i wyrozumiały system prawa jest podstawą bezpieczeństwa prowadzenia biznesu przez lata. Zjednoczone Emiraty Arabskie starają się w bardzo szerokim zakresie umożliwić zagranicznym inwestorom prowadzenie działalności gospodarczej. Przez wiele lat obserwowano pozytywny trend napływu inwestycji zagranicznych jednak wzrost podatków (podatek VAT) może ten wzrost w najbliższych latach znacząco zahamować.

\section{BIBLIOGRAFIA}

\section{ŹRÓDŁA PRAWA}

Konstytucja Zjednoczonych Emiratów Arabskich z dnia 2 grudnia 1996 r.

Ustawa Federalna nr 2 z dnia 1 kwietnia 2015 r. o spółkach handlowych [odpowiada 17 Dhi Al-Hijjah 1436 H. w kalendarzu muzułmańskim].

Ustawa z dnia 23 kwietnia 1964 r. Kodeks cywilny, Dz. U. Nr 16, poz. 93.

\footnotetext{
${ }^{31}$ BoncA, Islamskie instrumenty, s. 79.
} 


\title{
LITERATURA
}

ADAMEK Jacek: Mikrofinanse islamskie, Warszawa: CeDeWu 2010.

Bonca Mateusz A.: Islamskie instrumenty finansowe, Warszawa: Wydawnictwa Akademickie i Profesjonalne 2010.

Obaidullah Mohammed: Islamic Financial Services, Jeddah: Islamic Economics Research Center 2005.

\section{PROWADZENIE DZIAŁALNOŚCI GOSPODARCZEJ I JEJ OGRANICZENIA W ZJEDNOCZONYCH EMIRATACH ARABSKICH}

\author{
Streszczenie
}

Prowadzenie działalności gospodarczej w krajach muzułmańskich budzi wciąż wiele kontrowersji w świecie zachodu, który zasad funkcjonowania tamtejszych gospodarek niekiedy nie rozumie, a niekiedy nie chce zrozumieć, chociaż niektóre z nich, np. Emirat Dubaju, uchodzą za wzór rozwoju, nie tylko w świecie islamu. Na pojęcie wolności działalności gospodarczej należy patrzeć wielowymiarowo, nie tylko w kontekście danego kraju, lecz często w kontekście całego regionu, a nawet świata. Inwestorzy, po kryzysie stali się bardziej wymagający i szukają najlepszych miejsc do prowadzenia działalności gospodarczej. Ważnym elementem jest prezentowanie polityki otwartości na inwestorów zagranicznych przez sprawne i szybkie dostosowywanie przepisów do wymogów rynku. Elastyczny i wyrozumiały dla biznesu system prawa jest podstawą bezpieczeństwa prowadzenia biznesu przez lata. Zjednoczone Emiraty Arabskie starają się w bardzo szerokim zakresie umożliwić zagranicznym inwestorom prowadzenie działalności gospodarczej.

Słowa kluczowe: wolność gospodarcza; zakładanie działalności gospodarczej; Zjednoczone Emiraty Arabskie; strefy wolnocłowe; spółki offshore

\section{RUNNING A BUSINESS AND ITS RESTRICTIONS \\ IN THE UNITED ARAB EMIRATES}

\section{Sum mary}

Conducting business activity in Muslim countries still raises a lot of controversy in the Western World, which sometimes does not understand the principles of functioning of those economies, and sometimes does not want to understand, although some of them, for example Emirate of Dubai, are considered as a model of development, not only in the Islamic world. The concept of freedom of economic activity should be viewed in a multidimensional way, not only in the context of a given country, but often in the context of the whole region and even the world. Investors, after the crisis, have become more picky and are looking for the best places to do the run a business. An important element is the presentation of the policy of openness to foreign investors by efficient and quick adaptation of the regulations to market requirements. The legal system that is flexible and forgiving for business is the basis of business security for years. The United Arab Emirates is trying to allow foreign investors to run a business in a very wide range.

Key words: economic freedom; setting up a business; United Arab Emirates; free zones; offshore companies 